JOURNAL OF MANAGEMENT OF AQUATIC RESOURCES.

Volume 1, Nomor 1, Tahun 2012, Halaman 1-7

Online di : http://ejournal-s1.undip.ac.id/index.php/maquares

\title{
SEBARAN DAN KEPADATAN TERIPANG (HOLOTHUROIDEA) DI PERAIRAN PANTAI PULAU PRAMUKA, TAMAN NASIONAL KEPULAUAN SERIBU, JAKARTA
}

\author{
Uswatun Hasanah, Suryanti dan Bambang Sulardiono*) \\ Program Studi Manajemen Sumberdaya Perairan \\ Jurusan Perikanan Fakultas Perikanan dan Ilmu Kelautan Universitas Diponegoro \\ Jl. Prof. Soedharto, SH Semarang
}

\begin{abstract}
Abstrak
Penelitian ini dilakukan pada tanggal 9 - 22 April 2012 di Perairan Pantai Pulau Pramuka. Metode yang digunakan dalam penelitian ini adalah metode survey yang bersifat deskriptif. Pengambilan sampel teripang menggunakan metode kuadran transek. Pengambilan sampel dilakukan di 3 stasiun yaitu utara, timur dan selatan Pulau Pramuka. Hasil yang didapatkan pada penelitian ini yaitu Teripang yang didapatkan di perairan pantai Pulau Pramuka terdiri dari 6 spesies yaitu Synapta maculata, Euapta godefroyii, Holothuria leucospilota, Holothuria hilla, Holothuria edulis, dan Stichopus hermanni. Kepadatan teripang tertinggi pada stasiun I sebesar 0,0413 ind/600 $\mathrm{m}^{2}$ dan kepadatan teripang terendah pada stasiun III sebesar 0,0073 ind/600 $\mathrm{m}^{2}$. Nilai Sebaran (distribusi) teripang di tiga stasiun penelitian di Pulau Pramuka memiliki nilai indeks dispersi morisita 0,960, 0,929, dan -0,0012. Ketiga nilai tesebut I $<1$ sehingga pola penyebaran dikatakan seragam atau merata.
\end{abstract}

Kata Kunci: Teripang, Sebaran, Kepadatan

\begin{abstract}
This research was done on April 9 to 22, 2012 at Pramuka Island Coastal Waters. The method used in this study is descriptive survey. The sampling method of sea cucumbers is kuadran transect method, which was conducted at the north, east and south stations of Pramuka Island. The results obtained in the study of Sea cucumbers that are found in coastal waters of Pramuka Island are composed of six species of Synapta maculata, Euapta godefroyii, Holothuria leucospilota, Holothuria Hilla, Holothuria edulis and Stichopus hermanni. The highest density of sea cucumbers at the station I is $0.0413 \mathrm{ind} / 600 \mathrm{~m}^{2}$ and while the lowest density at station III is 0.0073 ind $/ 600 \mathrm{~m}^{2}$. The distribution of sea cucumbers at three stations in coastal waters of the Pramuka Island has morisita dispersion index value of 0.960, 0.929, and -0.0012. Those three values are $I \delta<1$, so it can be said that sea cucumbers in Pramuka Island are evenly spread/uniform.
\end{abstract}

Keyword: Sea Cucumber, Distribution, Density

\section{Pendahuluan}

Laut mempunyai potensi yang cukup besar sebagai penyedia sumber bahan makanan bagi penduduk. Laut merupakan habitat dari berbagai hewan dan tumbuhan yang mempunyai peran dan fungsi masingmasing. Indonesia merupakan wilayah yang memiliki potensi laut yang cukup besar, salah satunya adalah Teripang. Teripang memiliki potensi ekonomi yang cukup tinggi dan banyak dimanfaatkan oleh masyarakat sebagai bahan makanan dengan kandungan gizi yang cukup tinggi. Sehingga permintaan pasar internasional akan teripang semakin tinggi disamping ikan dan udang (Martoyo et al., 1994). Permasalahan sumberdaya teripang saat ini adalah terjadinya eksploitasi berlebihan terhadap induk-induk teripang yang berpotensi memijah dan kerusakan fisik habitat teripang. Hal tersebut juga terjadi di wilayah Kepulauan Seribu, kegiatan penangkapannya telah dilakukan para nelayan setempat sejak tahun 1973. Kegiatan ini dari waktu ke waktu semakin intensif, akibatnya populasi teripang di daerah ini semakin berkurang dan menurun terus Melihat prospek permintaan akan teripang yang cukup tinggi dan dengan sifat teripang yang pasif (bergerak lamban dan sangat mudah ditangkap), akan cenderung mendukung upaya penangkapan yang semakin intensif terutama dibeberapa wilayah perairan Kepulauan Seribu yang diduga merupakan habitat teripang. Hal ini dikhawatirkan populasi Teripang diKepulauan Seribu akan semakin menurun. Usaha pelestarian melalui restocking perlu dilakukan untuk mengurangi penangkapan yang berlebih. Guna menunjang kegiatan restocking tersebut terlebih dahulu dilakukan penelitian dasar guna mengetahui tingkat

\footnotetext{
${ }^{*}$ Penulis Penanggung Jawab
} 
kepadatan dan sebaran Teripang yang ada di Kepulauan Seribu sehingga dapat menunjang usaha pelestarian dan pembudidayaan di kawasan Konservasi Kepulaun Seribu tersebut. Tujuan dari penelitian yang dilaksanakan pada tanggal 9 - 22 April 2012 ini adalah untuk mengetahui sebaran dan kepadatan Teripang (Holothuroidea) di Perairan Pantai Pulau Pramuka Taman Nasional Kepulauan Seribu, Jakarta.

\section{Materi dan Metode Penelitian}

\section{A. Materi Penelitian}

Materi yang digunakan dalam penelitian ini yaitu teripang yang ditemukan di Perairan Pantai Pulau Pramuka, Kawasan Seksi Pengelolaan Taman Nasional III Kepulauan Seribu

\section{B. Metode Penelitian}

Metode yang digunakan adalah metode survey yang bersifat deskriptif (Notoatmodjo, 2002) Variabel yang diamati terdiri dari variabel utama (jenis-jenis teripang, kelimpahan relatif, kepadatan atau kelimpahan, distribusi) dan variabel penunjang (suhu, arus, salinitas, substrat, $\mathrm{pH}$ ). Sampling dilakukan di tiga stasiun berdasarkan perbedaan karakteristik substratnya. Stasiun 1 mewakili zona alami yang didominasi oleh substrat gravel, stasiun 2 mewakili zona pemukiman yang didominasi oleh substrat sand dan stasiun 3 yakni zona resort wisatawan yang didominasi oleh substrat sand. Data didapatkan dengan melakukan sampling di tiap stasiun dengan menggunakan metode kuadran transek. Jenis-jenis teripang yang ditemui dicocokkan dengan melihat referensi identifikasi teripang menurut buku Monograph of Shallow - Water Indo - West Pacific Echinoderms Clark and Rows (1971). Setelah data-data didapat, kemudian dilakukan pengolahan data yang terdiri dari kelimpahan, kelimpahan relatif, kepadatan, Indeks Morisita (Brower and Zar, 1977), dan uji One Way ANOVA . Variabel yang diuji yaitu Kepadatan Teripang dengan persentase substrat (gravel/sand/silt). Uji One Way ANOVA dilakukan dengan bantuan software SPSS 17.

\section{Hasil dan Pembahasan}

Jenis dan Kelimpahan Teripang

Jenis-jenis teripang yang ditemukan pada tiga stasiun penelitian tersaji pada Tabel 1.

Tabel 1. Jenis-jenis Teripang yang Ditemukan di Masing-masing Stasiun

\begin{tabular}{clccc}
\hline No. & \multicolumn{1}{c}{ Spesies } & Stasiun I & Stasiun II & Stasiun III \\
\hline 1. & Synapta maculata & + & + & + \\
2. & Euapta godeffroyi & + & + & - \\
3. & Holothuria leucospilota & + & + & + \\
4. & Holothuria hilla & + & - & - \\
5. & Holthuria edulis & - & + & + \\
6. & Stichopus hermanni & - & + & - \\
\hline
\end{tabular}

Pada lokasi Penelitian ditemukan 4 spesies yang termasuk ke dalam ordo Aspidochirotida dan Molpadida hal ini sesuai dengan yang dinyatakan oleh Bakus (1973) bahwa Aspidochirotida adalah hewan yang hidup didaerah tropik dengan karakteristik perairan yang jernih. Selanjutnya Hyman (1955) menyatakan bahwa daerah Indo Pasifik Barat merupakan daerah yang kaya akan teripang dari genus Holothuria dan Stichopus. Secara keseluruhan komposisi jenis teripang yang ditemukan di Pulau Pramuka tersaji pada Gambar 1.

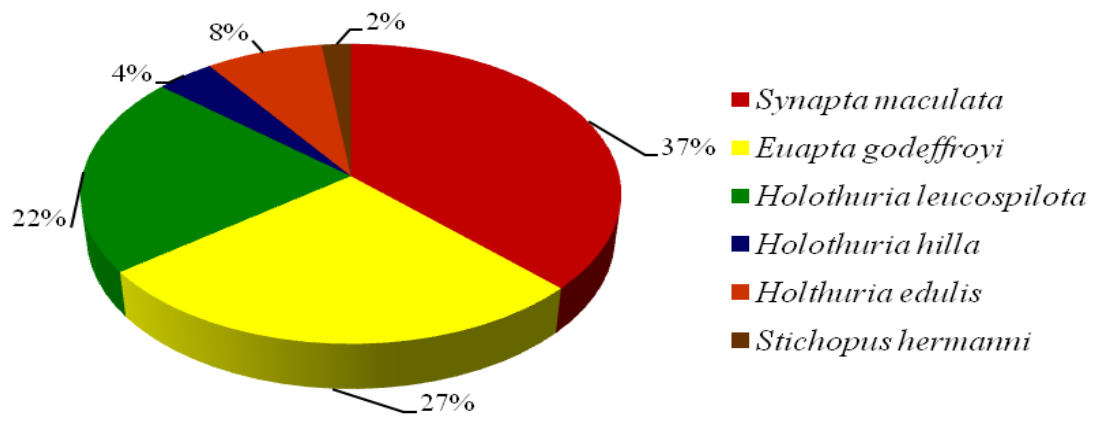

Gambar 1. Diagram Persentase Jumlah Teripang di Pulau Pramuka 
Dari jumlah individu yang ditemukan pada tiap stasiun pada Pulau Pramuka, maka diketahui kelimpahan relatif dari masing-masing spesies teripang yang ditemukan, dapat dilihat pada Tabel 2.

Tabel 2. Kelimpahan relatif (\%) Teripang di Pulau Pramuka

\begin{tabular}{clccc}
\hline No. & \multicolumn{1}{c}{ Spesies } & Stasiun I & Stasiun II & Stasiun III \\
\hline 1. & S. macullata & 44 & 27,3 & 50 \\
2. & E. godeffroyi & 36 & 22,7 & - \\
3. & H. leucospilota & 12 & 31,8 & 25 \\
4. & H. hilla & 8 & - & - \\
5. & H. edulis & - & 13,6 & 25 \\
6. & S. hermanni & - & 4,6 & - \\
\hline & & $\mathbf{1 0 0}$ & $\mathbf{1 0 0}$ & $\mathbf{1 0 0}$ \\
\hline
\end{tabular}

Kelimpahan relatif teripang yang ditemukan di pulau pramuka tersaji pada diagram kelimpahan relatif (\%) teripang pada Gambar 2.

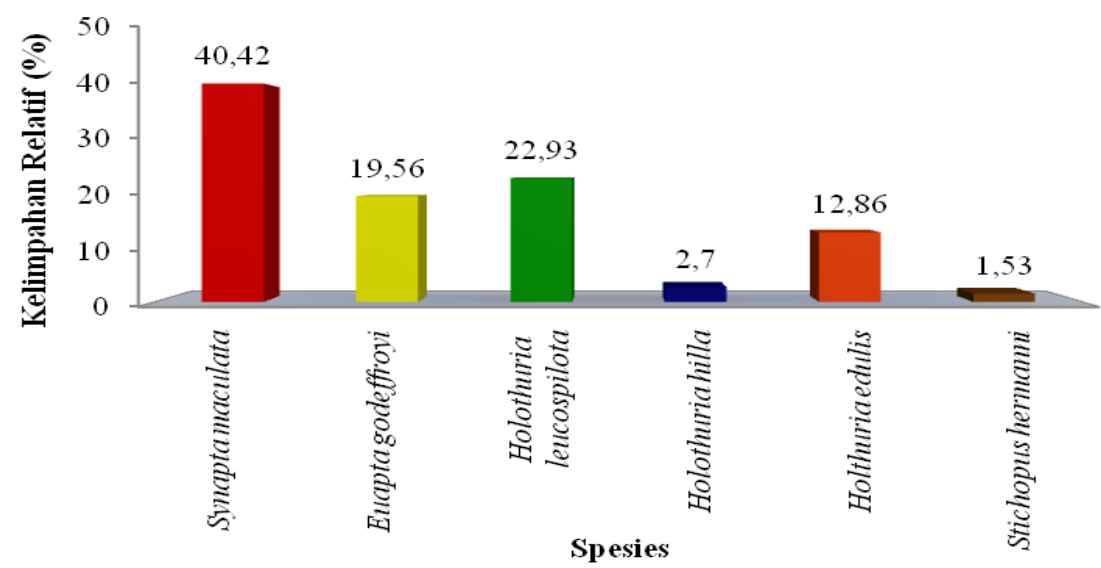

Gambar 2. Histogram Kelimpahan Relatif (\%) per Spesies Teripang di Pulau Pramuka

Hasil perhitungan kelimpahan relatif menunjukkan bahwa spesies S.maculata merupakan spesies yang memiliki nilai rerata kelimpahan relatif tinggi yaitu sebesar $40,42 \%$, berbanding terbalik dengan $S$. hermanni yang memiliki nilai rerata kelimpahan relatif terendah sebesar $1,53 \%$. Hal ini diduga karena $S$. maculata merupakan spesies non komersil, sehingga nelayan tidak banyak melakukan tangkapan lebih pada jenis ini, namun dibandingkan dengan $S$. hermanni yang merupakan spesies ekonomis penting banyak diburu oleh para nelayan.

\section{Sebaran (Distribusi) Teripang}

Hasil analisa sebaran (distribusi) teripang menggunakan Indeks Dispersi Morisita dapat diketahui sebaran (distribusi) Teripang di semua stasiun di Pulau Pramuka tersaji pada Tabel 3.

Tabel 3. Nilai Indeks Dispersi Morisita di Pulau Pramuka

\begin{tabular}{|c|c|c|c|}
\hline Indeks & Stasiun I & Stasiun II & Stasiun III \\
\hline 5. Indeks Morisita & 0,960 & 0,929 & $-0,0012$ \\
\hline 7. Jumlah Spesies & 25 & 22 & 4 \\
\hline
\end{tabular}

8.

Berdasarkan tabel 7 diatas indeks penyebaran morisita berkisar antara $-0,0012-0,960$ yang menunjukkan dimana I $\delta<1$ yang bearti sifat sebaran teripang diseluruh stasiun yaitu Seragam/Merata. Pola penyebaran ini banyak diakibatkan oleh rendahnya populasi setiap spesies dan adanya persaingan positif antar spesies dan dikarenakan adanya eksploitasi pada jenis-jenis teripang tertentu oleh nelayan.

Menurut odum (1971), sebaran seragam atau merata dapat terjadi dimana persaingan diantara individu sangat keras sehingga akan mendorong pembagian ruang, walaupun ada beberapa spesies yang lebih dominan daripada spesies yang lain. Spesies dominan dengan pola penyebaran seragam yang ditemukan pada beberapa stasiun penelitian diantaranya adalah S. maculata yang dominan di stasiun I, II, dan III. Secara 
umum pola penyebaran teripang dipengaruhi oleh kondisi lingkungan yang berhubungan dengan daya adaptasi. Ketersediaan makanan dan perlindungan terhadap pengaruh gelombang.

\section{Kepadatan Teripang}

Kepadatan teripang merupakan jumlah individu per satuan luas pengamatan. Berikut ini merupakan hasil analisis kepadatan teripang per stasiun pengamatan yang tersaji pada Tabel 4.

Tabel 4. Kepadatan Teripang (ind/600 $\mathrm{m}^{2}$ ) di Pulau Pramuka

\begin{tabular}{clccc}
\hline No. & \multicolumn{1}{c}{ Spesies } & Stasiun I & Stasiun II & Stasiun III \\
\hline 1. & S. maculata & 0,018 & 0,01 & 0,0033 \\
2. & E. godeffroyi & 0,015 & 0,0083 & 0 \\
3. & H. leucospilota & 0,005 & 0,012 & 0,002 \\
4. & H. hilla & 0,0033 & 0 & 0 \\
5. & H. edulis & 0 & 0,005 & 0,002 \\
6. & S. hermanni & 0 & 0,002 & 0 \\
\hline & Total & $\mathbf{0 , 0 4 1 3}$ & $\mathbf{0 , 0 3 7 3}$ & $\mathbf{0 , 0 0 7 3}$ \\
\hline
\end{tabular}

Secara keseluruhan spesies $S$. maculata merupakan jenis yang memiliki kepadatan rata-rata tertinggi dibandingkan dengan spesies teripang yang lain pada semua stasiun kepadatan rata-rata $0,0104 \mathrm{ind} / 600 \mathrm{~m}^{2}$ kemudian kepadatan rata-rata tertinggi lainnya adalah dari spesies $E$. godefroyii.

Kepadatan S. maculata dan E. godefroyii lebih tinggi dari pada teripang jenis lain, selain karena tingginya kemampuan kedua jenis teripang tersebut untuk menyesuaikan diri dengan kondisi lingkungan di perairan pantai pulau pramuka dibandingkan dengan teripang jenis lain dan merupakan spesies non ekonomis yang tidak banyak ditangkapa oleh nelayan, diduga hal tersebut juga disebabkan karena kedua spesies tersebut memiliki kemampuan melindungi diri dari perubahan kondisi lingkungan atau dari pemangsaan oleh predator serta gangguan lainnya.

Hasil uji statistik perbandingan contoh dengan metode one way Anova pada taraf nyata 0,05 di seluruh stasiun pengamatan yang terletak di Pulau Pramuka menghasilkan nilai sig 0,156 (probabilitas $\geq 0,05$ ), berarti tidak ada perbedaan yang nyata karakteristik tekstur substrat terhadap kepadatan teripang yang ditemukan di seluruh stasiun pengamatan. Hal ini menunjukkan bahwa kepadatan teripang yang ditemukan di tiap stasiun relatif seragam/merata dan sebaran pada ukuran tekstur substrat secara keseluruhan menyebar merata pada setiap stasiun dan tidak ada dominasi terhadap ukuran substrat tertentu, sehingga teripang. masih mampu melangsungkan kehidupannya melalui proses "bioturbation" yang telah berjalan secara terus menerus untuk keseimbangan ekosistemnya.

\section{Faktor Lingkungan Perairan}

Faktor lingkungan perairan meliputi Pengukuran faktor fisika dan kimia perairan. Pengukuran dilakukan pada tiap transek di tiap-tiap stasiun di Pulau Pramuka. Parameter yang diukur meliputi Suhu, Arus, Kecerahan, kedalaman, salinitas, dan $\mathrm{pH}$. Hasil penelitian parameter fisika dan kimia perairan selama penelitian tersaji pada Tabel 5.

Tabel 5. Hasil Pengukuran Parameter Fisika dan Kimia di Pulau Pramuka

\begin{tabular}{clcccc}
\hline No & \multicolumn{1}{c}{ Parameter } & Stasiun I & Stasiun II & Stasiun III & Kisaran Optimum \\
\hline 1. & Suhu $\left({ }^{0} \mathrm{C}\right)$ & 32 & 30 & 32 & $28-31^{\mathrm{a})}$ \\
2. & Arus $\left({ }^{m} / \mathrm{s}\right)$ & 0,044 & 0,238 & 0,061 & $0,30-0,50^{\mathrm{b})}$ \\
3. & Kecerahan & $\sim$ & $\sim$ & $\sim$ & - \\
4. & Kedalaman $(\mathrm{m})$ & $0,5-1$ & $0,5-1,5$ & $0,5-2$ & - \\
5. & Salinitas $(\% \mathrm{o})$ & 34 & 31 & 31 & $\left.30-37^{\mathrm{c}}\right)$ \\
6. & $\mathrm{Ph}$ & 8 & 7 & 7 & $7-8,5^{\mathrm{d})}$ \\
\hline
\end{tabular}

Sumber:

${ }^{a)}$ Hyman, 1955; 
${ }^{b)}$ Martoyo et al, 2006;

${ }^{c)}$ Departemen Kelautan dan Perikanan, 2004;

${ }^{\mathrm{d})}$ Effendie, 2003;

Hasil pengukuran suhu perairan selama penelitian pada setiap lokasi pengamatan berkisar antara 30 $32{ }^{\circ} \mathrm{C}$ dengan rata-rata $31,33{ }^{\circ} \mathrm{C}$. Hasil pengukuran suhu perairan pada lokasi penelitian masih tergolong layak bagi kehidupan teripang. Menurut Sutaman (1993), Teripang dapat hidup layak dengan suhu perairan berkisar anatara $28-32{ }^{\circ} \mathrm{C}$. Pengukuran salinitas pada setiap lokasi penelitian bervariasi berkisar antara 31-34 \%o dengan nilai rata-rata 31,67 \%o. Pada stasiun I (Utara) nilai salinitas 34 \%, pada stasiun II (timur) nilai salinitas $31 \%$ dan pada stasun III (selatan) nilai salinitas $31 \%$. Menurut Departemen Kelautan dan Perikanan (2004), kadar garam yang mendukung kehidupan teripang secara optimal adalah anatara 30 - 37 \%. Dengan demikian salinitas di tiap lokasi pengamatan mendukung kehidupan teripang. Derajat keasaman $(\mathrm{pH})$ di 3 stasiun perairan pantai pulau Pramuka yang tercatat selama penelitian mempunyai kisaran antara 7 - 8 yang berarti perairan dari kondisi netral menjadi sedikit basa. Pada stasiun I (utara) derajat keasaman $(\mathrm{pH})$ bernilai 8 yang berarti basa ini sesuai dengan pernyataan Saputra (2001) bahwa derajat keasaman $(\mathrm{pH})$ mempunyai pola yang mirip dengan suhu dimana nilai $\mathrm{pH}$ cenderung menurun pada saat suhu menurun begitu pula sebaliknya. Hal ini membuktikan bahwa pada stasiun I (utara) pulau pramuka yang suhunya tergolong hangat mengakibatkan nilai $\mathrm{pH}$ menjadi tinggi.

Hasil pengukuran kecepatan arus di pulau pramuka berkisar antara 0,044 - 0,238 m/detik. Arus pada stasiun II relatif sedikit cepat dibandingkan dengan stasiun I dan III, hal ini karena pada saat sampling pada stasiun II cuaca sedang berangin dan mendung diduga menyebabkan arus menjadi cepat. Arus di laut dipengaruhi oleh tiupan angin, perbedaan densitas air laut, dan gerakan periodik pasang surut. Kecerahan perairan yang tercatat di lokasi pengamatan umumnya sampai dasar dengan kedalaman berkisar antara 0,5 - 2 $\mathrm{m}$, hal ini berarti cahaya matahari dapat mencapai dasar perairan. Kecerahan perairan berhubungan dengan kesuburan perairan yaitu berlangsungnya kegiatan fotosintesis oleh plankton yang membutuhkan sinar matahari. Kecerahan yang mencapai kedalaman jauh ke dasar perairan memungkinkan masih berlangsungnya kegiatan fotosintesis oleh plankton sampai ke dasar perairan (Saputra, 2001

\section{Analisis Tekstur Substrat Dasar Perairan}

Hasil analisis tekstur substrat dasar perairan setiap stasiun pengamatan, nampak bahwa stasiun I (Utara) didominasi oleh tekstur substrat Gravel $(69,40 \%)$, stasiun II (Timur) Sand $(63,73 \%)$, dan stasiun III (Selatan) Sand $(51,16 \%)$ Untuk selengkapnya prosentase tekstur substrat pada setiap stasiun pengamatan dapat dilihat pada Tabel 6.

Tabel 6. Hasil Analisis Tekstur Substrat (\%) di Pulau Pramuka

\begin{tabular}{clccc}
\hline No & \multicolumn{1}{c}{ Tekstur Substrat } & Stasiun I & Stasiun II & Stasiun III \\
\hline 1. & Gravel (Kerikil/Pecahan Karang) & 69,40 & 32,97 & 38,43 \\
2. & Sand (Pasir) & 30,58 & 63,73 & 51,16 \\
3. & Silt (Endapan Limpur) & 0,02 & 3,30 & 10,41 \\
4. & Clay (Lanau) & 0 & 0 & 0 \\
\hline
\end{tabular}

Komposisi tekstur substrat dasar perairan yang didapatakan kemudian dianalisis menggunakan analisis cluster menggunakan software PAST untuk melihat tingkat kemiripan substrat antar stasiun. Dendogram hasil analisis cluster antar stasiun penelitian berdasarkan karakteristik tekstur substrat dasar perairan, tersaji pada Gambar 3. 


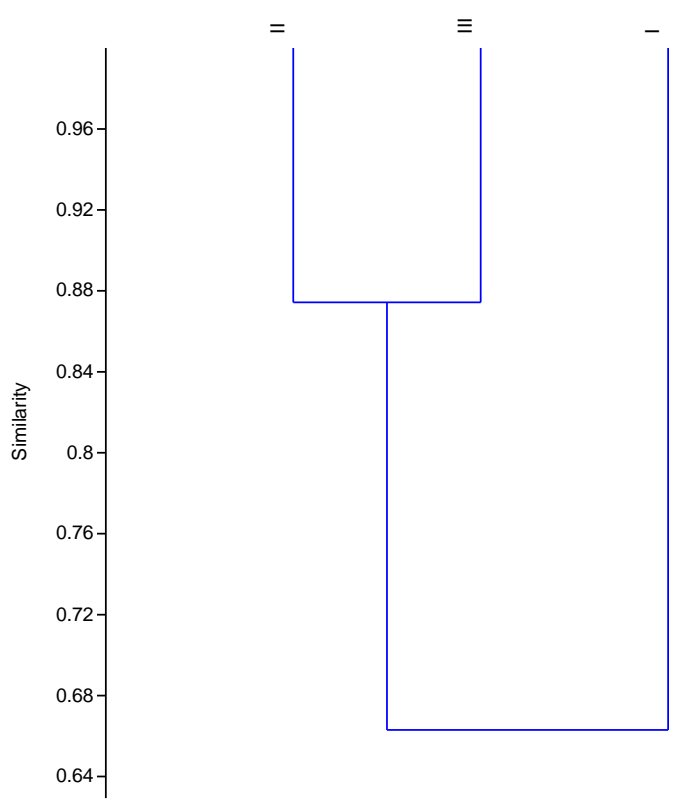

Gambar 3. Dendrogram Analisis Cluster Substrat Dasar Perairan

9.

Hasil analisis cluster karakteristik tekstur substrat dasar antar stasiun menunjukkan bahwa stasiun 2 (Timur) dan 3 (Selatan) mempunyai kemiripan yang sama dengan nilai sebesar 88\%. Secara keseluruhan spesies S. maculata merupakan jenis yang memiliki kepadatan rata-rata tertinggi dibandingkan dengan spesies teripang yang lain pada semua stasiun kepadatan rata-rata $0,0104 \mathrm{ind} / 600 \mathrm{~m}^{2}$ kemudian kepadatan rata-rata tertinggi lainnya adalah dari spesies $E$. godefroyii.

Kepadatan S. maculata dan E. godefroyii lebih tinggi dari pada teripang jenis lain, selain karena tingginya kemampuan kedua jenis teripang tersebut untuk menyesuaikan diri dengan kondisi lingkungan di perairan pantai pulau pramuka dibandingkan dengan teripang jenis lain dan merupakan spesies non ekonomis yang tidak banyak ditangkapa oleh nelayan, diduga hal tersebut juga disebabkan karena kedua spesies tersebut memiliki kemampuan melindungi diri dari perubahan kondisi lingkungan atau dari pemangsaan oleh predator serta gangguan lainnya.

Hasil uji statistik perbandingan contoh dengan metode one way Anova pada taraf nyata 0,05 di seluruh stasiun pengamatan yang terletak di Pulau Pramuka menghasilkan nilai sig 0,156 (probabilitas $\geq 0,05$ ), berarti tidak ada perbedaan yang nyata karakteristik tekstur substrat terhadap kepadatan teripang yang ditemukan di seluruh stasiun pengamatan. Hal ini menunjukkan bahwa kepadatan teripang yang ditemukan di tiap stasiun relatif seragam/merata dan sebaran pada ukuran tekstur substrat secara keseluruhan menyebar merata pada setiap stasiun dan tidak ada dominasi terhadap ukuran substrat tertentu, sehingga teripang. masih mampu melangsungkan kehidupannya melalui proses "bioturbation" yang telah berjalan secara terus menerus untuk keseimbangan ekosistemnya.

\section{Kesimpulan}

Berdasarkan hasil penelitian yang telah dilaksanakan dapat ditarik kesimpulan bahwa Sebaran teripang di tiga stasiun di perairan pantai pulau pramuka memiliki nilai indeks dispersi morisita $0,960,0,929$, dan 0,0012. Ketiga nilai menunjukkan bahwa $I \delta<1$ sehingga pola penyebaran seragam/merata dan Teripang yang didapatkan di perairan pantai Pulau Pramuka terdiri dari 6 spesies dimana kepadatan tertinggi pada stasiun I sebesar $0,0413 \mathrm{ind} / 600 \mathrm{~m}^{2}$ dan kepadatan terendah pada stasiun III sebesar $0,0073 \mathrm{ind} / 600 \mathrm{~m}^{2}$. 


\section{Daftar Pustaka}

Bakus, G.J. 1973. The Biologi and Ecology of Tropical Holothurians. Academic Press. New York.

Brower, J. H and J. H. Zar. 1977. General Zoology. Wim C Brown Company Publisher. Lowa.

Clark, A.M. and F.W.E. Rowe. 1971. Monograph of Shallow - Water Indo - West Pacific Echinoderms. Trust. Brit. Mus. Nat. Hist. 238 pp., 100 figs., 31 pls.

Departemen Kelautan dan Perikanan. 2004. Pedoman Monitoring Teripang. Departemen Kelautan dan Perikanan. Jakarta.

Effendi, H. 2003. Telaah kualitas air: Bagi Pengelolaan Sumberdaya dan Lingkungan Perairan. Kanisius. Yogyakarta.

Hana. 2011. Evaluasi Pemacuan Stok Teripang Pada Habitat Konservasi Lamun Pulau Pramuka, Kepulauan Seribu, Jakarta. Institut Pertanian Bogor. Bogor.

Hyman, L.H. 1955. The invertebrates: Echinidermata The Coelomnata Bilateria. Vol IV. Mc.Graw-Hill Book company. London.

Martoyo, J., N, Aji dan T, Winanto. 2006. Budidaya Teripang. Penebar Swadaya. Jakarta.

Notoatmodjo, S. 2002. Metodologi Penelitian Kesehatan. Rineka Cipta. Jakarta.

Odum, E. P. 1971. Fundamental Of Ecology $3^{\text {rd }}$ Edition. W. B Sounders Company. Philadelphia.

Purwati, P dan Ismiliana, W. 1988. Synaptidae (Echinodermata: Apodidae) dari Daerah Lamun Elnusa, Pulau Timur, Nusa Tenggara Timur. Pusat Penelitian Oseanografi - LIPI. Jakarta.

Saputra, D. A. 2001. Struktur Komunitas Teripang (Holothuroidae) di Perairan Pantai Pulau Pramuka dan Pulau Tikus Kepulauan Seribu Jakarta. Institut Pertanian Bogor. Bogor.

Sutaman, 1993. Petunjuk Praktis Budidaya Teripang. Kanisius. Yogyakarta. 